\title{
Retrospective analysis of breast cancer prognosis among young and older women in a Brazilian cohort of 738 patients, 1985-2002
}

\author{
FABIANA DE LIMA VAZQUEZ ${ }^{1}$, THIAGO BUOSI SILVA ${ }^{1}$, \\ RENÉ ALOÍSIO DA COSTA VIEIRA ${ }^{1,2}$, ALLINI MAFRA DA COSTA ${ }^{1}$, CRISTOVAM SCAPULATEMPO ${ }^{1}$, \\ JOSÉ HUMBERTO TAVARES GUERREIRO FREGNANI ${ }^{1}$, EDMUNDO CARVALHO MAUAD ${ }^{1}$, \\ ADHEMAR LONGATTO $^{3-5}$ and KARI JUHANI SYRJÄNEN ${ }^{1,6}$
}

\author{
${ }^{1}$ Department of Prevention, Barretos Cancer Hospital, Pio XII Foundation, Barretos, São Paulo 14784-400; \\ ${ }^{2}$ Department of Prevention, Faculty of Public Health, University of São Paulo, São Paulo 01246-904; ${ }^{3}$ Laboratory of Medical \\ Investigation 14, Department of Pathology, Medical School of São Paulo University, São Paulo 01246-903, Brazil; \\ ${ }^{4} 3 \mathrm{~B}$ 's-PT Government Associate Laboratory, Life and Health Sciences Research Institute (ICVS), School of Health Sciences, \\ University of Minho, Guimarães, 4710-057 Braga, Portugal; ${ }^{5}$ Molecular Oncology Research Center, \\ Barretos Cancer Hospital, Pio XII Foundation, Barretos, São Paulo 14784-400, Brazil; \\ ${ }^{6}$ Department of Clinical Research, Biohit HealthCare Ltd., 00880 Helsinki, Finland
}

Received September 3, 2015; Accepted May 16, 2016

DOI: $10.3892 / 01.2016 .5360$

\begin{abstract}
Invasive breast cancer (BC) is infrequent among women aged $\leq 40$ years, however, the disease outlook in these younger patients is generally worse than among older women. The present study aimed to compare socio-demographic, clinical and pathological characteristics, and their association with long-term survival, between two random cohorts of young ( $\leq 40$ years) and older (50-69 years) Brazilian patients with BC. The cohort comprised of 738 randomly selected women who were diagnosed with BC at Barretos Cancer Hospital, Pio XII Foundation (Barretos, Brazil) between January 1985 and December 2002; the patients included young women $(n=376)$ and older women $(n=362)$. The current analysis suggested that $\mathrm{BC}$ in young women is associated with numerous pathological features of aggressiveness. Second cancer and bilateral BC were independent predictors of a poor outcome in the younger group. Furthermore, C-erB-2 was positively correlated with poor outcome in the older group, whereas estrogen receptor status and TNM stage were associated with disease prognosis in both groups. The overall survival rates of the two age groups were similar except when analyzed according the treatment period (1997-2002). Although patients aged $\leq 40$ years harbored tumors with more aggressive clinicopathological
\end{abstract}

Correspondence to: Dr Fabiana de Lima Vazquez, Department of Prevention, Barretos Cancer Hospital, Pio XII Foundation, 1331 Rua Antenor Duarte Villela, Barretos, São Paulo 14784-400, Brazil E-mail: fabilivazquez@gmail.com

Key words: breast cancer, young women, disease outcome, prognostic factors, long-term follow-up, univariate/multivariate survival analysis characteristics, these characteristics were not independent predictors of overall survival. The present study indicates that medical advances associated with prevention of breast cancer may improve screening programs, which may therefore increase early diagnosis and subsequently lower mortality rates.

\section{Introduction}

Breast cancer (BC) is the most frequent malignancy among women worldwide, with an estimated 14 million new cases and 8 million mortalities in 2012, which is projected to rise by at least $70 \%$ by 2030 (1). It is most common in women aged $>50$ years ( $>75 \%$ of all cases), in contrast to those aged $\leq 40$ years, who represent only $5-25 \%$ of all BC cases. Notably, $\mathrm{BC}$ in these younger women is generally considered to bear a more unfavorable disease outcome, with a substantially shorter overall survival as compared with older women $(2,3)$.

Indeed, several multivariate analyses have shown that young age is an independent predictor of unfavorable disease outcome (4), and it has been suggested to be associated with a more aggressive tumor biology that potentially reduces the survival expectancy $(5,6)$. This increased aggressiveness of BC among younger women has been attributed to mutations in the $\mathrm{BC}$ susceptibility proteins, breast cancer (BRCA)1 and $2(5,6)$. In addition, $\mathrm{BC}$ in younger women is often diagnosed at more advanced stages than in older women. In addition, BC tumors in younger women are: i) More frequently negative for estrogen receptor (ER); ii) show extensive lymphovascular invasion (LVI); iii) exhibit increased cell proliferation (assessed by the Ki-67 marker); and v) demonstrate overexpression of p53 oncogene (6).

Molecular profiling has suggested that race and ethnicity may be other important factors associated with the development of BC, particularly with its poor prognosis among 
Table I. Demographics of patients with breast cancer stratified by age group.

\begin{tabular}{|c|c|c|c|c|c|}
\hline \multirow[b]{2}{*}{ Variable } & \multicolumn{2}{|c|}{$\leq 40$ years $(n=376)$} & \multicolumn{2}{|c|}{$50-69$ years $(n=362)$} & \multirow[b]{2}{*}{ P-value } \\
\hline & $\mathrm{n}$ & $\%$ & $\mathrm{n}$ & $\%$ & \\
\hline \multicolumn{6}{|c|}{ Period of treatment } \\
\hline $1985-1990$ & 59 & 15.7 & 65 & 18.0 & 0.078 \\
\hline 1991-1996 & 108 & 28.7 & 78 & 21.5 & \\
\hline 1997-2002 & 208 & 55.3 & 217 & 59.9 & \\
\hline $\mathrm{N} / \mathrm{A}$ & 1 & 0.3 & 2 & 0.6 & \\
\hline \multicolumn{6}{|l|}{ Schooling, years } \\
\hline $0-8$ & 210 & 55.9 & 279 & 77.1 & $<0.001$ \\
\hline $9-11$ & 106 & 28.2 & 32 & 8.8 & \\
\hline$\geq 12$ & 57 & 15.2 & 34 & 9.4 & \\
\hline $\mathrm{N} / \mathrm{A}$ & 3 & 0.8 & 17 & 4.7 & \\
\hline \multicolumn{6}{|l|}{ Overweight } \\
\hline No & 284 & 75.5 & 219 & 60.5 & $<0.001$ \\
\hline Yes & 44 & 11.7 & 90 & 24.9 & \\
\hline N/A & 48 & 12.8 & 53 & 14.6 & \\
\hline \multicolumn{6}{|l|}{ Ethnicity } \\
\hline White & 297 & 79.0 & 288 & 79.6 & 0.360 \\
\hline Non-white & 76 & 20.2 & 70 & 19.3 & \\
\hline N/A & 3 & 0.8 & 4 & 1.1 & \\
\hline \multicolumn{6}{|l|}{ Marital status } \\
\hline Married & 254 & 67.6 & 214 & 59.1 & $<0.001$ \\
\hline Single/divorced & 110 & 29.3 & 134 & 37.0 & \\
\hline $\mathrm{N} / \mathrm{A}$ & 12 & 3.2 & 14 & 3.9 & \\
\hline
\end{tabular}

N/A, not available.

younger women, with those of African American origin being at the highest risk of increased mortality (7). All of the aforementioned evidence indicates that $\mathrm{BC}$ in younger women bears a worse disease outcome compared with older women. This difference is only partially explained by the fact that mammography screening and clinical breast examinations are targeted to women aged $>40$ years (8).

In Brazil, the incidence and mortality rates of $\mathrm{BC}$ are relatively high $(9,10)$. Compared with North America, where the incidence of BC among younger women has plateaued (11), Brazil continues to present with relatively high incidence rates among women aged 30-39 years (12). Considering the increased BC mortality among young women of African origin (7), it is of note that Brazil is a country with a relatively high population of African descent, increasing the importance of assessing the characteristics of $\mathrm{BC}$ among young women in this country.

To the best of our knowledge, the present study analyzed the largest cohort of patients with BC aged $\leq 40$ years $(n=376)$ at a single institution to date, by comparing an extensive set of clinicopathological characteristics and other variables with a similarly sized cohort of BC patients aged 50-69 years $(n=362)$. The aim of the present study was to determine whether disease outcome in younger women is poorer than that in the older women and, if supported, to estimate the significant determinants of this differential outcome in multivariate models.

\section{Patients and methods}

Study design. The present retrospective analytical study was based on the hospital records of women with invasive $\mathrm{BC}$ (ICD-10: C50) who were admitted to Barretos Cancer Hospital, Pio XII Foundation (Barretos, Brazil) with no previous treatment between January 1985 and December 2002. During this 17-year period, a total of 4,134 women were examined. Of those, 1,735 women were eligible and initially selected into the present study, according to the inclusion and exclusion criteria. The patients were divided into two groups: A younger group ( $\leq 40$ years of age) and an older group (50-69 years of age). The original cohort included 469 patients aged $\leq 40$ years and 1,266 patients aged 50-69 years. From this original cohort, 400 women were selected from each group using a random sample generator (SPSS software, version 20.0.0.1; IBM SPSS, Armonk, NY, USA). Clinical treatment and follow-up data were obtained from the patients' medical records. Patients without follow-up information for $>12$ months were contacted by telephone to update this information.

Inclusion and exclusion criteria. Patients that had undergone cancer treatment prior to admission (1,290 patients), those aged 41-49 years of age (666 patients) and those aged $\geq 70$ years (443 patients) were excluded from the cohort. Finally, 24 women were excluded from the $\leq 40$ years age group and 38 women were 
Table II. Main clinical features of patients with breast cancer stratified by age group.

\begin{tabular}{|c|c|c|c|c|c|}
\hline \multirow[b]{2}{*}{ Clinical feature } & \multicolumn{2}{|c|}{$\leq 40$ years $(n=376)$} & \multicolumn{2}{|c|}{$50-69$ years $(n=362)$} & \multirow[b]{2}{*}{ P-value } \\
\hline & $\mathrm{n}$ & $\%$ & $\mathrm{n}$ & $\%$ & \\
\hline \multicolumn{6}{|l|}{ Palpable nodules } \\
\hline No & 19 & 5.1 & 20 & 5.5 & 0.761 \\
\hline Yes & 356 & 94.7 & 338 & 93.4 & \\
\hline $\mathrm{N} / \mathrm{A}$ & 1 & 0.3 & 4 & 1.1 & \\
\hline \multicolumn{6}{|l|}{ Multicentric cancer } \\
\hline No & 358 & 95.2 & 344 & 95.0 & 0.158 \\
\hline Yes & 11 & 2.9 & 5 & 1.4 & \\
\hline N/A & 7 & 1.9 & 12 & 3.3 & \\
\hline Multifocal cancer & & & & & 0.017 \\
\hline No & 346 & 92.9 & 341 & 94.2 & \\
\hline Yes & 23 & 6.1 & 9 & 2.5 & \\
\hline $\mathrm{N} / \mathrm{A}$ & 1 & 0.3 & 12 & 3.3 & \\
\hline \multicolumn{6}{|l|}{ Second cancer } \\
\hline No & 371 & 98.7 & 352 & 97.2 & 0.327 \\
\hline Yes & 4 & 1.1 & 7 & 1.9 & \\
\hline N/A & 8 & 2.1 & 3 & 0.8 & \\
\hline Bilateral breast cancer & & & & & 0.037 \\
\hline No & 331 & 88.0 & 336 & 92.8 & \\
\hline Yes & 37 & 9.8 & 21 & 5.8 & \\
\hline N/A & 8 & 2.1 & 5 & 1.4 & \\
\hline \multicolumn{6}{|l|}{ Familial history } \\
\hline No & 211 & 56.1 & 181 & 50.0 & 0.611 \\
\hline Yes & 49 & 13.0 & 36 & 9.9 & \\
\hline Other malignancies & 74 & 19.7 & 53 & 14.6 & \\
\hline N/A & 42 & 11.2 & 92 & 25.4 & \\
\hline \multicolumn{6}{|l|}{ Menopause at diagnosis } \\
\hline No & 363 & 96.5 & 38 & 10.5 & $<0.001$ \\
\hline Yes & 7 & 1.9 & 226 & 62.4 & \\
\hline N/A & 6 & 1.6 & 98 & 27.1 & \\
\hline Comorbidities & & & & & $<0.001$ \\
\hline Absent & 256 & 68.1 & 145 & 40.1 & \\
\hline 1 or 2 diseases & 114 & 30.8 & 175 & 48.3 & \\
\hline N/A & 6 & 1.6 & 42 & 11.6 & \\
\hline
\end{tabular}

N/A, not available.

excluded from the 50-69 years age group due to a lack of clinical or treatment information, or due to a non-invasive disease.

Sample size estimation. To calculate the sample size, the following assumptions were made: $30-40 \%$ mortality $(13,14)$, $\pm 7.5 \%$ estimation error, $5 \%$ type I error and $90 \%$ power. These conditions indicated that between 360 and 400 patients in both groups would be required for an adequately powered study. Accordingly, the final analysis included 376 women aged $\leq 40$ years and 362 women aged 50-69 years.

Definitions of BC characteristics. BC was defined as multi-centric or multi-focal disease. Multi-centric was defined as a disease present in $>1$ quadrant of the breast, whereas multi-focal disease was defined as a second tumor located at a distance of at least $5 \mathrm{~cm}$ from the primary tumor. The tumors were also classified as synchronous or metachronous. The criteria recommended by the National Cancer Institute were used to assess comorbidities (15).

Immunohistochemistry (IHC) was routinely performed using paraffin sections of the tumors to classify their patterns of ER, progesterone receptor (PR) and C-erB-2 oncoprotein expression. Tumors that were negative for all of these markers were considered 'triple negative' for IHC expression. Assessment of positive reactions was performed according to the guidelines in common use for ER and PR, and the scoring system proposed by Allred et al was used to determine the proportion of stained nuclei and the staining intensity (16). 
Table III. Histological features of patients with breast cancer stratified by age group.

\begin{tabular}{|c|c|c|c|c|c|}
\hline \multirow[b]{2}{*}{ Histological feature } & \multicolumn{2}{|c|}{$\leq 40$ years $(n=376)$} & \multicolumn{2}{|c|}{$50-69$ years $(n=362)$} & \multirow[b]{2}{*}{ P-value } \\
\hline & $\mathrm{n}$ & $\%$ & $\mathrm{n}$ & $\%$ & \\
\hline \multicolumn{6}{|l|}{ Histological diagnosis } \\
\hline Ductal carcinoma & 301 & 80.1 & 289 & 79.8 & \multirow[t]{4}{*}{0.867} \\
\hline Lobular carcinoma & 59 & 15.7 & 54 & 14.9 & \\
\hline Miscellaneous & 15 & 4.0 & 17 & 4.7 & \\
\hline N/A & 1 & 0.3 & 2 & 0.6 & \\
\hline \multicolumn{6}{|c|}{ Tumor size (mastectomy), $\mathrm{cm}$} \\
\hline$\leq 2$ & 54 & 14.4 & 74 & 20.4 & \multirow[t]{3}{*}{0.185} \\
\hline$>2$ & 187 & 49.7 & 195 & 53.9 & \\
\hline N/A & 135 & 35.9 & 93 & 25.7 & \\
\hline \multicolumn{6}{|l|}{$\mathrm{T}^{\mathrm{a}}$} \\
\hline TI/TII & 196 & 52.1 & 210 & 58.0 & \multirow[t]{3}{*}{0.354} \\
\hline TIII/TIV & 84 & 22.3 & 106 & 29.3 & \\
\hline N/A & 94 & 25.0 & 46 & 12.7 & \\
\hline \multicolumn{6}{|l|}{$\mathrm{N}^{\mathrm{a}}$} \\
\hline Positive & 147 & 39.1 & 156 & 43.1 & \multirow[t]{3}{*}{0.183} \\
\hline Negative & 197 & 52.4 & 170 & 47.0 & \\
\hline N/A & 32 & 8.5 & 36 & 9.9 & \\
\hline \multicolumn{6}{|l|}{$\mathrm{M}^{\mathrm{a}}$} \\
\hline No & 311 & 82.7 & 311 & 85.9 & \multirow[t]{3}{*}{0.740} \\
\hline Yes & 38 & 10.1 & 35 & 9.7 & \\
\hline N/A & 27 & 7.2 & 16 & 4.4 & \\
\hline \multicolumn{6}{|l|}{ Differentiation degree } \\
\hline $\mathrm{I} / \mathrm{II}$ & 190 & 50.5 & 201 & 55.5 & \multirow[t]{3}{*}{0.035} \\
\hline III & 87 & 23.1 & 60 & 16.6 & \\
\hline N/A & 99 & 26.3 & 101 & 27.9 & \\
\hline \multicolumn{6}{|l|}{ Perineural invasion } \\
\hline No & 241 & 64.1 & 84 & 23.2 & \multirow{3}{*}{0.055} \\
\hline Yes & 18 & 4.8 & 13 & 3.6 & \\
\hline N/A & 117 & 31.1 & 276 & 76.8 & \\
\hline \multicolumn{6}{|l|}{ Blood vessel invasion } \\
\hline No & 248 & 66.0 & 79 & 21.8 & \multirow{3}{*}{0.007} \\
\hline Yes & 4 & 1.1 & 7 & 1.9 & \\
\hline $\mathrm{N} / \mathrm{A}$ & 124 & 33.0 & 276 & 76.2 & \\
\hline Lymphovascular inva & & & & & \\
\hline No & 189 & 50.3 & 53 & 14.6 & $<0.001$ \\
\hline Yes & 80 & 21.3 & 81 & 22.4 & \\
\hline N/A & 107 & 28.5 & 228 & 63.0 & \\
\hline Lymph node invasion & & & & & \\
\hline N1 $(1-3)$ & 78 & 20.7 & 67 & 18.5 & 0.535 \\
\hline N2 (4-9) & 55 & 14.6 & 49 & 13.5 & \\
\hline $\mathrm{N} 3(\geq 10)$ & 42 & 11.2 & 35 & 9.7 & \\
\hline N/A & 201 & 53.5 & 211 & 58.3 & \\
\hline Estrogen receptor & & & & & \\
\hline Negative & 89 & 23.7 & 67 & 18.5 & 0.014 \\
\hline Positive & 126 & 33.5 & 155 & 42.8 & \\
\hline $\mathrm{N} / \mathrm{A}$ & 161 & 42.8 & 140 & 38.7 & \\
\hline Progesterone recepto & & & & & \\
\hline Negative & 90 & 23.9 & 85 & 23.5 & 0.468 \\
\hline Positive & 124 & 33.0 & 135 & 37.3 & \\
\hline $\mathrm{N} / \mathrm{A}$ & 162 & 43.1 & 142 & 39.2 & \\
\hline
\end{tabular}


Table III. Continued.

\begin{tabular}{|c|c|c|c|c|c|}
\hline \multirow[b]{2}{*}{ Histological feature } & \multicolumn{2}{|c|}{$\leq 40$ years $(n=376)$} & \multicolumn{2}{|c|}{$50-69$ years $(n=362)$} & \multirow[b]{2}{*}{ P-value } \\
\hline & $\mathrm{n}$ & $\%$ & $\mathrm{n}$ & $\%$ & \\
\hline \multicolumn{6}{|l|}{ C-erB-2 oncoprotein } \\
\hline Negative & 117 & 31.3 & 125 & 34.5 & 0.032 \\
\hline Positive & 58 & 15.4 & 53 & 14.6 & \\
\hline $\mathrm{N} / \mathrm{A}$ & 201 & 53.5 & 184 & 50.8 & \\
\hline \multicolumn{6}{|l|}{ Triple negative } \\
\hline No & 136 & 36.2 & 155 & 42.8 & 0.027 \\
\hline Yes & 38 & 10.1 & 23 & 6.4 & \\
\hline N/A & 202 & 53.7 & 184 & 50.8 & \\
\hline \multicolumn{6}{|c|}{ Type of breast surgery } \\
\hline Without surgery & 37 & 9.8 & 24 & 6.6 & 0.078 \\
\hline Lumpectomy & 26 & 6.9 & 36 & 9.9 & \\
\hline Quadrantectomy & 87 & 23.1 & 66 & 18.2 & \\
\hline Mastectomy & 224 & 59.6 & 234 & 65.6 & \\
\hline $\mathrm{N} / \mathrm{A}$ & 2 & 0.5 & 2 & 0.6 & \\
\hline \multicolumn{6}{|l|}{ Axillary surgery } \\
\hline No & 58 & 15.4 & 62 & 17.1 & 0.219 \\
\hline Yes & 316 & 84.0 & 298 & 82.3 & \\
\hline $\mathrm{N} / \mathrm{A}$ & 2 & 0.5 & 2 & 0.6 & \\
\hline \multicolumn{6}{|c|}{ Number of lymph nodes dissected } \\
\hline $1-10$ & 61 & 16.2 & 53 & 14.6 & 0.762 \\
\hline $11-15$ & 76 & 20.2 & 77 & 21.3 & \\
\hline $16-20$ & 77 & 20.5 & 86 & 23.8 & \\
\hline$\geq 2$ & 151 & 40.2 & 144 & 39.8 & \\
\hline $\mathrm{N} / \mathrm{A}$ & 11 & 2.9 & 2 & 0.6 & \\
\hline
\end{tabular}

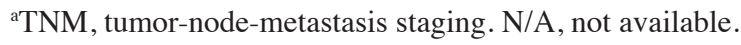

Tumor staging was based on the criteria proposed by the International Union Against Cancer and the American Joint Committee on Cancer (17), and the TNM staging system was used to evaluate the $\mathrm{BC}$ in three aspects: Tumor size and extension $(\mathrm{T})$, regional lymph node involvement $(\mathrm{N})$, and the presence of distant metastasis (M). Following the determination of the T, $\mathrm{N}$ and $\mathrm{M}$ classifications, stage $0, \mathrm{I}, \mathrm{II}, \mathrm{III}$ or IV was assigned.

Statistical analysis. Statistical analyses were run using SPSS software for Windows (version 20.0.0.1; IBM SPSS). Frequency tables used for univariate analysis of overall survival (OS; the time from diagnosis until mortality or date last seen alive) were based on the Kaplan-Meier method, where stratum-specific outcomes were compared using log-rank (Mantel-Cox) statistics. To adjust for covariates, a Cox proportional hazards regression model was used, and covariates (as listed separately) were entered in a stepwise backwards manner using the default values of entry $(\mathrm{P}=0.05)$ and removal $(\mathrm{P}=0.10)$. The variables that were significant in the univariate analysis were included in the multivariate model. All of the statistical tests were two-sided and $\mathrm{P}<0.05$ indicated a statistically significant difference.

Ethics. The present study was approved by the Research Ethics Committee of Barretos Cancer Hospital, Pio XII Foundation.

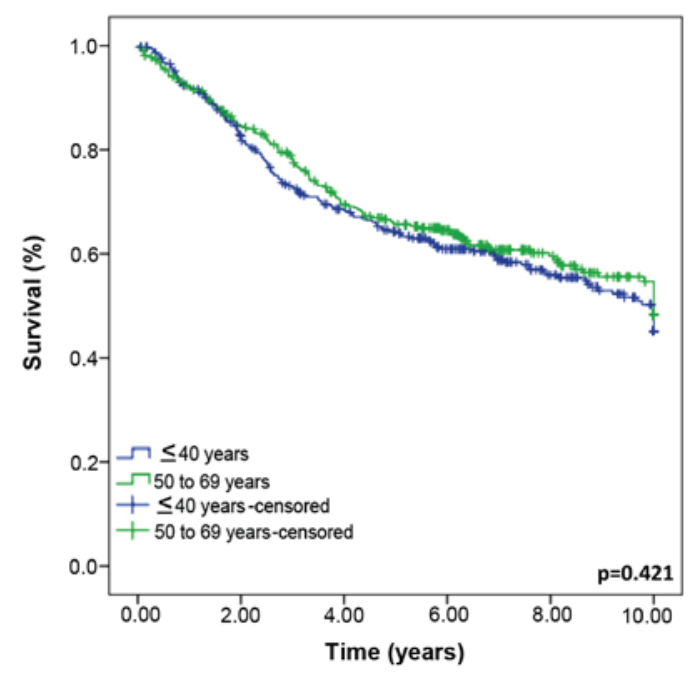

Figure 1. Overall survival rates of younger $(n=376)$ and older $(n=362)$ women with breast cancer.

\section{Results}

The demographic characteristics of the patients in the two series are presented in Table I. The main clinical features are 
Table IV. Treatment of patients with breast cancer, stratified by age group.

\begin{tabular}{|c|c|c|c|c|c|}
\hline \multirow[b]{2}{*}{ Treatment } & \multicolumn{2}{|c|}{$\leq 40$ years $(n=376)$} & \multicolumn{2}{|c|}{$50-69$ years $(\mathrm{n}=362)$} & \multirow[b]{2}{*}{ P-value } \\
\hline & $\mathrm{n}$ & $\%$ & $\mathrm{n}$ & $\%$ & \\
\hline \multicolumn{6}{|c|}{ Breast reconstruction } \\
\hline Without & 295 & 78.5 & 346 & 95.6 & \multirow[t]{4}{*}{$<0.001$} \\
\hline Immediate & 35 & 9.3 & 6 & 1.7 & \\
\hline Late & 43 & 11.4 & 8 & 2.2 & \\
\hline N/A & 3 & 0.8 & 2 & 0.6 & \\
\hline \multicolumn{6}{|c|}{ Neoadjuvant chemotherapy } \\
\hline No & 312 & 83.0 & 286 & 79.0 & \multirow[t]{3}{*}{0.254} \\
\hline Yes & 62 & 16.5 & 71 & 19.6 & \\
\hline N/A & 2 & 0.5 & 5 & 1.4 & \\
\hline \multicolumn{6}{|l|}{ Chemotherapy } \\
\hline No & 52 & 13.8 & 70 & 19.3 & \multirow[t]{4}{*}{0.053} \\
\hline Yes (adjuvant) & 201 & 53.5 & 196 & 54.1 & \\
\hline Yes (palliative) & 120 & 31.9 & 92 & 25.4 & \\
\hline N/A & 3 & 0.8 & 4 & 1.1 & \\
\hline \multicolumn{6}{|l|}{ Hormone therapy } \\
\hline No & 206 & 54.8 & 176 & 48.6 & \multirow{4}{*}{0.056} \\
\hline Yes (adjuvant) & 104 & 27.7 & 131 & 36.2 & \\
\hline Yes (palliative) & 59 & 15.7 & 51 & 14.1 & \\
\hline N/A & 7 & 1.9 & 4 & 1.1 & \\
\hline \multicolumn{6}{|l|}{ Radiotherapy } \\
\hline No & 69 & 18.4 & 72 & 19.9 & \multirow[t]{3}{*}{0.592} \\
\hline Yes & 302 & 80.3 & 284 & 78.5 & \\
\hline N/A & 5 & 1.3 & 6 & 1.7 & \\
\hline
\end{tabular}

N/A, not available.

shown in Table II. The histopathological features and treatment characteristics are shown in Tables III and IV, respectively.

The two groups displayed significant differences in various characteristics. The older group showed a higher proportion of women with low educational level (up to 8 years of school) as compared with the younger group (77.1 vs. $55.9 \%$, respectively; $\mathrm{P}<0.001)$ (Table I).

Table II shows that the groups had no differences in the presence of nodules or multicentric cancer at the first examination. The younger group had a higher proportion of multi-focal cancer and bilateral cancer as compared with the older group (6.1 vs. $2.5 \%, \mathrm{P}=0.017$ and 9.8 vs. $5.8 \%, \mathrm{P}=0.037$, respectively). Comorbidity was less frequent in the younger group than in the older group; one or two comorbidities were found in 30.3 vs. $48.3 \%$ of patients $(\mathrm{P}<0.001)$, respectively (Table II).

As indicated in Table III, no significant differences were identified between the groups in terms of histological types of the cancer or disease staging. The tumors in the younger group showed a greater frequency of a low degree of differentiation (23.1 vs. $16.6 \% ; \mathrm{P}=0.035)$, reduced blood vessel invasion (1.1 vs. $1.9 \% ; \mathrm{P}=0.003)$, reduced LVI (21.3 vs. $22.4 \% ; \mathrm{P}<0.001)$ and reduced perineural invasion ( 4.8 vs. $3.6 \% ; \mathrm{P}=0.055)$ as compared with the lesions in the older group (Table III).
The proportion of tumors that were positive for ER expression was significantly lower in the younger group than in the older group (33.5 vs. $42.8 \%$; $\mathrm{P}=0.014)$. The two groups had similar negative rates of PR and C-erB-2 expression (Table III). Tumors classified as triple negative were more frequent among the younger women $(10.1$ vs. $6.4 \% ; \mathrm{P}=0.027)$ (Table III).

The two groups were similar in terms of the number of dissected lymph nodes. Although the younger group underwent radical mastectomy less frequently than the older group, the difference was not statistically significant (59.6 vs. $64.6 \%$, respectively; $\mathrm{P}=0.078$ ) (Table III). There was a higher proportion of breast reconstruction in the younger group as compared with the older group (20.7 vs. 3.9\%; P<0.001) (Table IV). Furthermore, the groups had undergone similar neo-adjuvant treatments Table IV); adjuvant hormone therapy was used less frequently in the younger than in the older group, but this difference was only of borderline significance (27.7 vs. $36.2 \%$; $\mathrm{P}=0.056$ ) (Table IV).

The duration of follow-up ranged between 0 and 22.6 years, with a mean of 6.1 years and 8.5 months when mortality was excluded. The follow-up data were similar in the two groups $(\mathrm{P}=0.816)$. After 5 and 10 years, 4.9 and $10.5 \%$ of the patients, respectively, were lost to follow-up (data not shown). The 
Table V. DSS according to the demographics of patients with breast cancer, stratified by age group.

\begin{tabular}{|c|c|c|c|c|c|c|}
\hline \multirow[b]{2}{*}{ Variable } & \multicolumn{3}{|c|}{$\leq 40$ years $(n=376)$} & \multicolumn{3}{|c|}{$50-69$ years $(n=362)$} \\
\hline & $\mathrm{n}$ & 10-year DSS, \% & P-value & $\mathrm{n}$ & 10-year DSS, \% & P-value \\
\hline \multicolumn{7}{|l|}{ Period of treatment } \\
\hline $1985-1990$ & 59 & 46.1 & 0.656 & 65 & 33.3 & 0.002 \\
\hline 1991-1996 & 108 & 46.4 & & 78 & 42.0 & \\
\hline 1997-2002 & 208 & 40.7 & & 217 & 60.0 & \\
\hline $\mathrm{N} / \mathrm{A}$ & 1 & & & 2 & & \\
\hline \multicolumn{7}{|l|}{ Schooling, years } \\
\hline $0-8$ & 210 & 42.5 & 0.751 & 279 & 50.0 & 0.551 \\
\hline $9-11$ & 106 & 48.5 & & 32 & 44.6 & \\
\hline$\geq 12$ & 57 & 47.5 & & 34 & 38.5 & \\
\hline N/A & 3 & & & 17 & & \\
\hline \multicolumn{7}{|l|}{ Overweight } \\
\hline No & 284 & 48.1 & 0.624 & 219 & 47.5 & 0.978 \\
\hline Yes & 44 & 34.1 & & 90 & 44.9 & \\
\hline N/A & 48 & & & 53 & & \\
\hline \multicolumn{7}{|l|}{ Ethnicity } \\
\hline White & 297 & 46.0 & 0.534 & 288 & 50.1 & 0.129 \\
\hline Non-white & 76 & 42.7 & & 70 & 41.0 & \\
\hline N/A & 3 & & & 4 & & \\
\hline \multicolumn{7}{|l|}{ Marital status } \\
\hline Married & 254 & 44.2 & 0.538 & 214 & 52.2 & 0.170 \\
\hline Single/divorced & 110 & 49.5 & & 134 & 42.6 & \\
\hline $\mathrm{N} / \mathrm{A}$ & 12 & & & 14 & & \\
\hline
\end{tabular}

DSS, disease-specific survival; N/A, not available.

OS rates were not significantly different between the groups $(\mathrm{P}=0.421)$ (Fig. 1).

Univariate analysis showed that the following characteristics were significantly associated with prognosis in the younger group: Second cancer $(\mathrm{P}=0.004)$, bilateral $\mathrm{BC}(\mathrm{P}=0.100)$, familial history $(\mathrm{P}=0.086)$, menopause at diagnosis $(\mathrm{P}=0.026)$, associated diseases $(\mathrm{P}=0.077)$, tumor size (mastectomy) $(\mathrm{P}=0.075), \mathrm{T}$, $\mathrm{N}$ and $\mathrm{M}$ stage $(\mathrm{P}<0.001)$, degree of differentiation $(\mathrm{P}=0.127)$, perineural invasion $(\mathrm{P}=0.056), \mathrm{LVI}(\mathrm{P}=0.004)$, lymph node invasion $(\mathrm{P}<0.001)$, ER status $(\mathrm{P}=0.002)$, $\mathrm{PR}$ status $(\mathrm{P}=0.043)$, type of breast surgery $(\mathrm{P}<0.001)$, axillary surgery $(\mathrm{P}<0.001)$, number of lymph nodes dissected $(\mathrm{P}<0.001)$, breast reconstruction $(\mathrm{P}<0.001)$, neoadjuvant chemotherapy $(\mathrm{P}<0.028)$, chemotherapy $(\mathrm{P}<0.001)$ and hormone therapy $(\mathrm{P}<0.001)$ (Tables V-VIII).

In the older group, the following variables were significantly associated with prognosis: Period of treatment $(\mathrm{P}=0.002)$, ethnicity $(\mathrm{P}=0.129)$, marital status $(\mathrm{P}=0.170)$, palpable nodules ( $\mathrm{P}=0.062)$, tumor size (mastectomy) $(\mathrm{P}=0.042), \mathrm{T}, \mathrm{N}$ and $\mathrm{M}$ stage $(\mathrm{P}<0.001)$, degree of differentiation $(\mathrm{P}<0.001)$, peri-neural invasion $(\mathrm{P}=0.095)$, blood vessel invasion $(\mathrm{P}<0.001)$, LVI $(\mathrm{P}=0.003)$, lymph node invasion $(\mathrm{P}<0.001)$, ER status $(\mathrm{P}=0.001)$, $\mathrm{PR}$ status $(\mathrm{P}=0.015), \mathrm{C}$-erB-2 expression $(\mathrm{P}=0.006)$, type of breast surgery $(\mathrm{P}<0.001)$, axillary surgery $(\mathrm{P}<0.001)$, number of lymph nodes dissected $(\mathrm{P}=0.005)$, neo-adjuvant chemotherapy $(\mathrm{P}=0.010)$, chemotherapy $(\mathrm{P}<0.001)$, hormone therapy $(\mathrm{P}<0.001)$, and radiotherapy $(\mathrm{P}=0.016)$. None of the other variables were statistically significant predictors of survival (Tables V-VIII).

When stratified by clinical stage, no significant differences in the stage-specific survival rates between the two age groups were found ( $\mathrm{P}=0.421$ ) (Fig. 1). However, when the groups were stratified by the period of treatment, significant differences in survival rates were observed between the two groups during the treatment period between 1997 and 2002 (young vs. old group, 40.7 vs. $60.0 \%$ survival, $\mathrm{P}=0.028$ ) (Fig. 2).

In the multivariate analysis, second cancer [hazard ratio (HR), 2.20; 95\% confidence interval (CI), 1.500-29.044; $\mathrm{P}=0.013]$ and bilateral $\mathrm{BC}(\mathrm{HR}, 6.60 ; 95 \% \mathrm{CI}, 1.228-3.930$; $\mathrm{P}=0.008$ ) were independent predictors of a poor outcome, with an increased risk of mortality in the younger group. C-erB-2 (HR, 1.97; 95\%; CI, 1.003-3.869; $\mathrm{P}=0.049$ ) was a positive predictor of a poor outcome in the older group, showing an increased risk of mortality. The ER status and TNM stage were significantly associated with disease prognosis in both groups (Tables IX and X).

\section{Discussion}

The results described herein reveal important differences between the younger and older patients with $\mathrm{BC}$. This is an almost unanimously accepted fact among $\mathrm{BC}$ investigators. 
Table VI. DSS according to the clinical characteristics of patients with breast cancer, stratified by age group.

\begin{tabular}{|c|c|c|c|c|c|c|}
\hline \multirow[b]{2}{*}{ Clinical characteristic } & \multicolumn{3}{|c|}{$\leq 40$ years $(n=376)$} & \multicolumn{3}{|c|}{$50-69$ years $(n=362)$} \\
\hline & $\mathrm{n}$ & 10-year DSS, \% & P-value & $\mathrm{n}$ & 10-year DSS, \% & P-value \\
\hline \multicolumn{7}{|l|}{ Palpable nodules } \\
\hline No & 19 & 66.7 & 0.216 & 20 & 78.9 & 0.062 \\
\hline Yes & 356 & 43.9 & & 338 & 46.3 & \\
\hline $\mathrm{N} / \mathrm{A}$ & 1 & & & 4 & & \\
\hline \multicolumn{7}{|l|}{ Multicentric cancer } \\
\hline No & 358 & 46.8 & 0.413 & 344 & 48.9 & 0.428 \\
\hline Yes & 11 & 26.0 & & 5 & 50.0 & \\
\hline N/A & 7 & & & 12 & & \\
\hline \multicolumn{7}{|l|}{ Multifocal cancer } \\
\hline No & 346 & 6.2 & 0.799 & 341 & 48.4 & 0.634 \\
\hline Yes & 23 & 43.3 & & 9 & 66.7 & \\
\hline $\mathrm{N} / \mathrm{A}$ & 1 & & & 12 & & \\
\hline \multicolumn{7}{|l|}{ Second cancer } \\
\hline No & 371 & 45.7 & 0.004 & 352 & 47.8 & 0.545 \\
\hline Yes & 4 & 25.0 & & 7 & 71.4 & \\
\hline N/A & 8 & & & 3 & & \\
\hline \multicolumn{7}{|l|}{ Bilateral breast cancer } \\
\hline No & 331 & 48.5 & 0.100 & 336 & 48.8 & 0.575 \\
\hline Yes & 37 & 30.1 & & 21 & 46.2 & \\
\hline N/A & 8 & & & 5 & & \\
\hline \multicolumn{7}{|l|}{ Familial history } \\
\hline No & 211 & 38.8 & 0.086 & 181 & 54.9 & 0.495 \\
\hline Yes & 49 & 56.7 & & 36 & 61.7 & \\
\hline Other malignancies & 74 & 46.6 & & 53 & 36.0 & \\
\hline N/A & 42 & & & 92 & & \\
\hline \multicolumn{7}{|l|}{ Menopause at diagnosis } \\
\hline No & 363 & 45.4 & 0.026 & 38 & 28.5 & 0.283 \\
\hline Yes & 7 & 19.0 & & 226 & 45.4 & \\
\hline N/A & 6 & & & 98 & & \\
\hline \multicolumn{7}{|l|}{ Associated diseases } \\
\hline Absent & 256 & 40.2 & 0.077 & 145 & 53.1 & 0.925 \\
\hline 1 or 2 diseases & 114 & 55.7 & & 175 & 42.8 & \\
\hline$\geq 3$ diseases & 5 & 40.0 & & 40 & 46.3 & \\
\hline $\mathrm{N} / \mathrm{A}$ & 1 & & & 2 & & \\
\hline
\end{tabular}

DSS, disease-specific survival; N/A, not available.

Notably, however, the present study was unable to confirm the most controversial of these issues, the suggested worse survival rate of young patients with $\mathrm{BC}$, and failed to identify any difference in disease outcome between the two study groups. This finding is of major importance, asthe OS (Kaplan-Meier) did not reveal significant differences between the two groups, despite several parameters indicating that a more aggressive tumor biology is confined to the younger patients. Only when calculated for the treatment period 1997-2002 were the OS rates significantly worse among young women. We propose that there are several explanations for this finding, with insights discussed herein.
Whether there are clinicopathological differences in BC between younger and older women remains a controversial issue. Typically, the young $\mathrm{BC}$ age group ranges from $35(13,18,19)$ to $40(2,14,20,21)$, however, there is no clear consensus supporting these strict age limits for young and old. However, BC is more frequent in women aged $>50$ years old. In a population-derived cohort from Brazil, the prevalence of $\mathrm{BC}$ was found to be $14 \%$ (12), $4.5 \%$ of these patients were aged $\leq 35$ years (3) and $26.4 \%$ were aged $\leq 40$ years (2).

Thus, in the present study, a 40-year cut-off was used to stratify the women as younger or older. This criterion was partially supported by epidemiological data demonstrating 
Table VII. OS according to the histological characteristics of patients with breast cancer, stratified by age group.

\begin{tabular}{|c|c|c|c|c|c|c|}
\hline \multirow[b]{2}{*}{ Histological characteristic } & \multicolumn{3}{|c|}{$\leq 40$ years $(n=376)$} & \multicolumn{3}{|c|}{$50-69$ years $(n=362)$} \\
\hline & $\mathrm{n}$ & 10 -year OS, \% & $\mathrm{P}$-value & $\mathrm{n}$ & 10 -year OS, \% & P-value \\
\hline \multicolumn{7}{|l|}{ Histological diagnosis } \\
\hline Ductal carcinoma & 301 & 47.8 & 0.212 & 289 & 46.4 & 0.429 \\
\hline Lobular carcinoma & 59 & 32.4 & & 54 & 58.2 & \\
\hline Miscellaneous & 15 & 53.0 & & 17 & 58.5 & \\
\hline N/A & 1 & & & 2 & & \\
\hline \multicolumn{7}{|l|}{ Tumor size (mastectomy) } \\
\hline$\leq 2 \mathrm{~cm}$ & 54 & 65.0 & 0.075 & 74 & 57.1 & 0.042 \\
\hline$>2 \mathrm{~cm}$ & 187 & 49.9 & & 195 & 52.1 & \\
\hline N/A & 135 & & & 93 & & \\
\hline \multicolumn{7}{|l|}{ Stage } \\
\hline I & 38 & 90.9 & $<0.001$ & 37 & 66.8 & $<0.001$ \\
\hline II & 136 & 66.2 & & 135 & 67.6 & \\
\hline III & 101 & 20.4 & & 122 & 28.3 & \\
\hline IV & 44 & 0.049 & & 39 & - & \\
\hline $\mathrm{N} / \mathrm{A}$ & 57 & & & 29 & & \\
\hline \multicolumn{7}{|l|}{$\mathrm{T}^{\mathrm{a}}$} \\
\hline TI/TII & 196 & 56.8 & $<0.001$ & 210 & 62.8 & $<0.001$ \\
\hline TIII/TIV & 84 & 32.6 & & 106 & 26.5 & \\
\hline $\mathrm{N} / \mathrm{A}$ & 94 & & & 46 & & \\
\hline \multicolumn{7}{|l|}{$\mathrm{N}^{\mathrm{a}}$} \\
\hline Negative & 147 & 70.3 & $<0.001$ & 156 & 70.1 & $<0.001$ \\
\hline Positive & 197 & 32.3 & & 170 & 33.3 & \\
\hline N/A & 32 & & & 36 & & \\
\hline \multicolumn{7}{|l|}{$\mathrm{M}^{\mathrm{a}}$} \\
\hline No & 311 & 50.1 & $<0.001$ & 311 & 50.4 & $<0.001$ \\
\hline Yes & 38 & - & & 34 & - & \\
\hline $\mathrm{N} / \mathrm{A}$ & 27 & & & 17 & & \\
\hline \multicolumn{7}{|l|}{ Differentiation degree } \\
\hline $\mathrm{I} / \mathrm{II}$ & 190 & 45.1 & 0.127 & 201 & 58.0 & $<0.001$ \\
\hline III & 87 & 46.9 & & 60 & 23.5 & \\
\hline $\mathrm{N} / \mathrm{A}$ & 99 & & & 101 & & \\
\hline \multicolumn{7}{|l|}{ Perineural invasion } \\
\hline No & 241 & 47.3 & 0.056 & 84 & 65.0 & 0.095 \\
\hline Yes & 18 & - & & 13 & - & \\
\hline N/A & 117 & & & 278 & & \\
\hline \multicolumn{7}{|l|}{ Blood vessel invasion } \\
\hline No & 248 & 45.9 & 0.431 & 79 & 68.7 & $<0.001$ \\
\hline Yes & 4 & - & & 7 & - & \\
\hline $\mathrm{N} / \mathrm{A}$ & 124 & & & 276 & & \\
\hline \multicolumn{7}{|l|}{ Lymphovascular invasion } \\
\hline No & 189 & 53.8 & 0.004 & 53 & 76.8 & 0.003 \\
\hline Yes & 80 & 30.5 & & 81 & 29.4 & \\
\hline N/A & 107 & & & 228 & & \\
\hline \multicolumn{7}{|l|}{ Lymph node invasion } \\
\hline $\mathrm{N} 1$ (1 to 3) & 78 & 53.7 & $<0.001$ & 67 & 52.2 & $<0.001$ \\
\hline N2 (4 to 9) & 55 & 34.8 & & 49 & 13.8 & \\
\hline N3 $(\geq 10)$ & 42 & 14.4 & & 35 & - & \\
\hline N/A & 201 & & & 211 & & \\
\hline
\end{tabular}


Table VII. Continued.

\begin{tabular}{|c|c|c|c|c|c|c|}
\hline \multirow[b]{2}{*}{ Histological characteristic } & \multicolumn{3}{|c|}{$\leq 40$ years $(n=376)$} & \multicolumn{3}{|c|}{$50-69$ years $(\mathrm{n}=362)$} \\
\hline & $\mathrm{n}$ & 10-year OS, \% & P-value & $\mathrm{n}$ & 10 -year OS, \% & P-value \\
\hline \multicolumn{7}{|l|}{ Estrogen receptor } \\
\hline Negative & 89 & 16.7 & 0.002 & 67 & 31.2 & 0.001 \\
\hline Positive & 126 & 47.8 & & 155 & 60.4 & \\
\hline N/A & 161 & & & 140 & & \\
\hline \multicolumn{7}{|l|}{ Progesterone receptor } \\
\hline Negative & 90 & 16.2 & 0.043 & 85 & 46.3 & 0.015 \\
\hline Positive & 124 & 49.0 & & 135 & 56.4 & \\
\hline N/A & 162 & & & 142 & & \\
\hline \multicolumn{7}{|l|}{ C-erB-2 oncoprotein } \\
\hline Negative & 117 & 33.0 & 0.332 & 125 & 66.5 & 0.006 \\
\hline Positive & 58 & 18.9 & & 53 & 50 & \\
\hline $\mathrm{N} / \mathrm{A}$ & 201 & & & 184 & & \\
\hline \multicolumn{7}{|l|}{ Triple negative } \\
\hline No & 136 & 25.2 & 0.711 & 155 & 69 & 0.236 \\
\hline Yes & 38 & 26.0 & & 23 & 68.8 & \\
\hline N/A & 202 & & & 184 & & \\
\hline \multicolumn{7}{|l|}{ Type of breast surgery } \\
\hline Without surgery & 37 & - & $<0.001$ & 24 & - & $<0.001$ \\
\hline Lumpectomy & 26 & 0 & & 36 & 35.3 & \\
\hline Quadrantectomy & 87 & 61.6 & & 66 & 75.7 & $<0.001$ \\
\hline Mastectomy & 224 & 47.9 & & 234 & 46.6 & \\
\hline N/A & 2 & & & 2 & & \\
\hline \multicolumn{7}{|l|}{ Axillary surgery } \\
\hline No & 58 & 0 & $<0.001$ & 62 & 24.1 & $<0.001$ \\
\hline Yes & 316 & 51.8 & & 298 & 52.3 & \\
\hline N/A & 2 & & & 2 & & \\
\hline \multicolumn{7}{|c|}{ Number of lymph nodes dissected } \\
\hline 1 to 10 & 61 & 61.1 & $<0.001$ & 53 & 53.3 & 0.005 \\
\hline 11 to 15 & 76 & 43.9 & & 77 & 42 & \\
\hline 16 to 20 & 77 & 63.8 & & 86 & 58.7 & \\
\hline 21 and over & 151 & 25.1 & & 144 & 40.9 & \\
\hline N/A & 11 & & & 2 & & \\
\hline
\end{tabular}

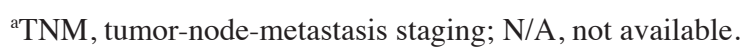

different tumor biology in different age groups $(14,22)$. It is also important to emphasize that in Europe, regular mammography screening is a standard practice for women aged 50-69 years. This group is considered to be a biologically distinct group at high risk of developing BC with particular radiological characteristics (23). For this reason, women aged 50-69 years old were selected for comparison in the present study. As BC studies have different definitions regarding age groups, it is challenging to provide a reasonable comparison between different studies.

A number of reports also disagree regarding the importance of including different types of $\mathrm{BC}$, for example, carcinoma in situ (CIS) $(13,21)$ or metastatic disease $(2,24)$. Other studies disagree regarding the pertinence of including patients with clinical stage I and II $(25,26)$ or clinical stages I-III $(2,20,24)$ cancer. The present study included TNM stage, and excluded cases of CIS due to their different histological features (27) and relatively favorable disease outcome.

The present study is based on robust parameters that were selected to reflect the true significance of the behavior of $\mathrm{BC}$ in young women. To the best of our knowledge, the current study includes the largest cohort of patients with BC aged $\leq 40$ years $(n=376)$ reported from a single institution to date. Worldwide, few institutions have studied larger samples $(24,28)$ and the majority of large studies have been based on cancer registries $(7,14,21)$. 
Table VIII. DSS according to the treatment of patients with breast cancer, stratified by age group.

\begin{tabular}{|c|c|c|c|c|c|c|}
\hline \multirow[b]{2}{*}{ Treatment } & \multicolumn{3}{|c|}{$\leq 40$ years $(n=376)$} & \multicolumn{3}{|c|}{$50-69$ years $(n=362)$} \\
\hline & $\mathrm{n}$ & 10-year DSS, \% & P-value & $\mathrm{n}$ & 10-year DSS, \% & P-value \\
\hline \multicolumn{7}{|c|}{ Breast reconstruction } \\
\hline Without & 295 & 41.0 & $<0.001$ & 346 & 47.7 & 0.263 \\
\hline Immediate & 35 & 43.3 & & 6 & - & \\
\hline Late & 43 & 75.7 & & 8 & 83.3 & \\
\hline $\mathrm{N} / \mathrm{A}$ & 3 & & & 2 & & \\
\hline \multicolumn{7}{|c|}{ Neoadjuvant chemotherapy } \\
\hline No & 312 & 48.4 & 0.028 & 286 & 51.0 & 0.010 \\
\hline Yes & 62 & 28.2 & & 71 & 37.3 & \\
\hline $\mathrm{N} / \mathrm{A}$ & 2 & & & 5 & & \\
\hline \multicolumn{7}{|l|}{ Chemotherapy } \\
\hline No & 52 & 65.5 & $<0.001$ & 70 & 49.6 & $<0.001$ \\
\hline Yes-adjuvant & 201 & 60.9 & & 196 & 62.5 & \\
\hline Yes-palliative & 120 & 14.0 & & 92 & 19.0 & \\
\hline N/A & 3 & & & 4 & & \\
\hline \multicolumn{7}{|l|}{ Hormone therapy } \\
\hline No & 206 & 51.8 & 0.001 & 176 & 52.5 & $<0.001$ \\
\hline Yes-adjuvant & 104 & 50.3 & & 131 & 53.2 & \\
\hline Yes-palliative & 59 & 10.8 & & 51 & 11.2 & \\
\hline $\mathrm{N} / \mathrm{A}$ & 7 & & & 4 & & \\
\hline \multicolumn{7}{|l|}{ Radiotherapy } \\
\hline No & 69 & 50.5 & 0.935 & 72 & 36.7 & 0.016 \\
\hline Yes & 302 & 43.2 & & 284 & 52.9 & \\
\hline N/A & 5 & & & 6 & & \\
\hline
\end{tabular}

DSS, disease-specific survival; N/A, not available.

Table IX. Multivariate survival analysis of patients aged $\leq 40$ years $(n=178)$.

\begin{tabular}{|c|c|c|c|c|}
\hline Variable & $\mathrm{n}$ & Hazard ratio & $95 \%$ confidence interval & P-value \\
\hline \multicolumn{5}{|c|}{ Bilateral breast cancer } \\
\hline No & 158 & - & - & - \\
\hline Yes & 20 & 2.20 & $1.228-3.930$ & 0.008 \\
\hline \multicolumn{5}{|c|}{ Second cancer } \\
\hline No & 176 & - & - & - \\
\hline Yes & 2 & 6.60 & $1.500-29.044$ & 0.013 \\
\hline \multicolumn{5}{|c|}{ Estrogen receptor } \\
\hline Positive & 106 & - & - & - \\
\hline Negative & 72 & 2.29 & $1.389-3.777$ & 0.001 \\
\hline \multicolumn{5}{|l|}{$\mathrm{T}$} \\
\hline $\mathrm{I} / \mathrm{II}$ & 133 & - & - & - \\
\hline III/IV & 45 & 2.14 & $1.258-3.640$ & 0.005 \\
\hline \multicolumn{5}{|l|}{$\mathrm{N}$} \\
\hline No & 80 & - & - & - \\
\hline Yes & 98 & 2.66 & $1.531-4.621$ & 0.001 \\
\hline \multicolumn{5}{|l|}{ M } \\
\hline No & 173 & - & - & - \\
\hline Yes & 5 & 5.92 & $2.172-16.151$ & 0.001 \\
\hline
\end{tabular}


Table X. Multivariate survival analysis of patients aged $50-69$ years $(n=151)$.

\begin{tabular}{|c|c|c|c|c|}
\hline Variable & $\mathrm{n}$ & Hazard ratio & $95 \%$ confidence interval & P-value \\
\hline \multicolumn{5}{|c|}{ Estrogen receptor } \\
\hline Positive & 44 & - & - & - \\
\hline Negative & 107 & 2.34 & $1.175-4.663$ & 0.016 \\
\hline \multicolumn{5}{|c|}{ C-erB-2 oncoprotein } \\
\hline Negative & 108 & - & - & - \\
\hline Positive & 43 & 1.97 & $1.003-3.869$ & 0.049 \\
\hline \multicolumn{5}{|l|}{$\mathrm{T}^{\mathrm{a}}$} \\
\hline $\mathrm{I} / \mathrm{II}$ & 110 & - & - & - \\
\hline III/IV & 41 & 2.12 & $1.073-4.180$ & 0.030 \\
\hline \multicolumn{5}{|l|}{$\mathrm{N}^{\mathrm{a}}$} \\
\hline No & 71 & - & - & - \\
\hline Yes & 80 & 2.93 & $1.394-6.149$ & 0.005 \\
\hline \multicolumn{5}{|l|}{$M^{\mathrm{a}}$} \\
\hline No & 150 & - & - & - \\
\hline Yes & 1 & 9.99 & $1.049-95.105$ & 0.045 \\
\hline
\end{tabular}

${ }^{a}$ TNM, tumor-node-metastasis staging.

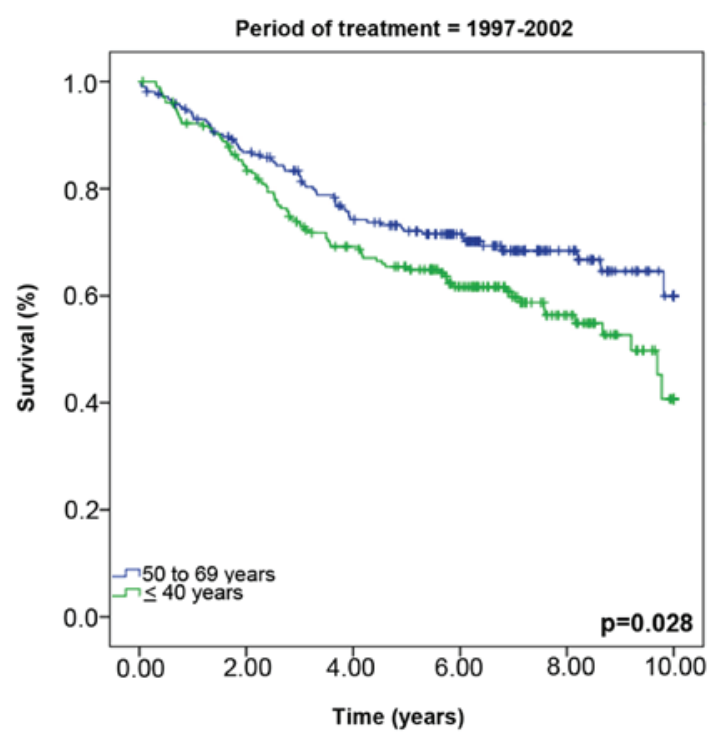

Figure 2. Overall survival rates of younger $(n=208)$ and older $(n=217)$ women with breast cancer in the treatment period between 1997 and 2002.

The present study included a large number of patients with invasive $\mathrm{BC}$ presenting at advanced clinical stages. These features are not unusual and are inherent to the existing healthcare system in Brazil. Brazilian women have limited access to clinics that provide mammography examinations and organized population-based screening programs do not exist; consequently, the majority of the BC cases in Brazil are detected at advanced stages. This is in contrast to the situation in developed countries, where regular mammography screening enables the detection of the majority of cases of BC at an early stage $(14,19,21)$. Indeed, prior to 2002 , there was no formal recommendation from the Brazilian Health Authorities to provide mammography examinations in asymptomatic women. Therefore, as the presence of palpable and/or ulcerated lesions were a requirement for medical care, a substantial proportion of women exhibited these signs at their first examination. These characteristics are an inherent bias of the present study design resulting in a cohort enriched by $\mathrm{BC}$ patients with aggressive tumors at baseline. However, the overall relative survival rate of the older women (50-69 years old) improved between 1997 and 2002, attributable to improvements in treatment, such as chemotherapy and hormone therapy (29).

Mammography is undoubtedly an important diagnostic tool for non-palpable lesions, despite sensitivity limitations among women aged $\leq 40$ years. It is speculated that regular programs for BC prevention could minimize the number of cases of advanced stage disease in Brazil (30). Hereditary BC associated with BRCA1/2 mutations have a prevalence of $2.3 \%$ (31) in Brazil. Furthermore, studies of Latin American women have demonstrated that a family history of BC is less prevalent in Latin America than in the North American population (32). In the present study, mutations were not investigated, however, the familial history of BC was similar between the two study groups. However, the presence of second cancer was similar in the younger and older groups; this is consistent with the results of a previous study, where it was attributed to longer exposures to pathogenic factors (33).

The prevalence of bilateral disease was higher in the younger age group and is one of the indicators of more aggressive tumors, for example tumors with T stage II/III, grade III differentiation, negative ER/PR status and positive lymph node invasion are more aggressive (33). Conversely, the older women more frequently presented with other diseases associated with their BC, which can have an adverse influence on clinical outcome and contribute to a poor prognosis (34). However, the present results identified indicators of worse prognosis to be more common among the younger women. 
Accordingly, younger women presented with a higher proportion of tumors with grade III differentiation (poorly differentiated), as reported in a previous study (33). Similarly, the present study observed significant differences between the two groups in terms of perivascular blood vessel invasion and LVI, with older women showing higher proportions of both types of invasion. Notably, this result conflicts with the previously reported data $(35,36)$.

The present study also observed that a higher proportion of older women were positive for ER compared with younger women. This finding is consistent with the results of a previous study, in which advanced age was correlated with positive ER status and vice versa (36). This observation also agrees with the disease outcome data of the current cohort, as a negative ER status is typically associated with a more unfavorable prognosis. By contrast, PR expression did not significantly differ between the two age groups, in agreement with a previous report (26). Conversely, a previous study observed that a negative PR status occurs more frequently in the BC of younger women (35). However, the prognostic value of PR was visible only as a part of an algorithm, but not on its own (37). The present findings also revealed that triple negative $\mathrm{BC}$, which are considered to predict a poor prognosis, were more common in younger women, as previously reported (13).

As anticipated, more important differences in factors that usually influence the efficacy of treatment were observed between the two groups, including tumor stage at the time of diagnosis, tumor characteristics and comorbidities. Of note, the present study included patients with follow-up times of up to 22 years (mean, 6.75 years). This is another important feature of the present study, as only a small number of studies have reported long-term follow-up data of $10(20,25,36,38)$ or 15 years $(2,14,24,28)$. In addition, BC treatment strategies have undergone rapid developments in the past two decades, and this development may have contributed to the prognostic differences between the two groups included in the current study. In the younger group, fewer patients received adjuvant hormone therapy and more women received palliative chemotherapy when compared with the older group. This is a clear limitation inherent to all retrospective studies where active intervention is no longer possible. However, the current observations clearly support proposals to also initiate monitoring programs for long-term BC patients.

Finally, the present results did not show significant differences in survival rates between the two study groups (Fig. 1). By contrast, a previous study conducted in central Brazil demonstrated a significant difference in survival rates between patients aged $\leq 40$ years and those aged $40-50$ years $(\mathrm{P}=0.0002)$ or those aged $>50$ years $(\mathrm{P}=0.03)$. However, this study excluded clinical stage IV disease and included far fewer patients than the present study (20). A previous study reported that BC mortality remains high among young patients, with an OS of $\sim 60 \%$ over 5 years, compared with $85 \%$ among women aged $>50$ years (20). The equal survival rates between young and old women observed in the present study have been reported in previous studies $(38,39)$, however, in general, the results have been highly variable among the published literature (40-43).

In conclusion, BC among young women is generally considered to be more aggressive and associated with a worse prognosis compared with $\mathrm{BC}$ in older women, whereas the prognostic value of age itself remains more controversial. The results of the present study suggest that BC in young women is associated with numerous pathological features of aggressiveness, including tumor grade, hormone receptor status and degree of differentiation, having been implicated as independent determinants of BC prognosis. However, the OS rates of the two age groups proved to be very similar, except when the data were stratified by the treatment period. For women treated during 1997-2002, the 10-year survival rate of the older women was $\sim 60 \%$ compared with $40.7 \%$ in the younger cohort. The current study concludes that this increase in 10-year survival is due largely to improvements in treatment, increased early diagnosis and certain tumor characteristics, with the patient's age itself not being an independent prognostic factor. The present study indicates that medical advances associated with prevention of breast cancer may improve screening programs, which may therefore increase early diagnosis and subsequently lower mortality rates.

\section{Acknowledgements}

The authors thank the Public Ministry of Labor (Research, Prevention and Education of Occupational Cancer) in Campinas, Brazil, and the Lions Club of Brazil for partial financial support of the present study and Dr. Vinicius de Lima Vazquez (Department of Skin cancer and Melanoma, Barretos Cancer Hospital, Pio XII Foundation, Barretos, Brazil) for assistance with the statistical analysis. The abstract was previously published in The Breast 23 (Suppl): S11, 2014.

\section{References}

1. Antoni S, Soerjomataram I, Møller B, Bray F and Ferlay J: An assessment of GLOBOCAN methods for deriving national estimates of cancer incidence. Bull World Health Organ 94: 174-184, 2016.

2. Elkum N, Dermime S, Ajarim D, Al-Zahrani A, Alsayed A, Tulbah A, Al Malik O, Alshabanah M, Ezzat A and Al-Tweigeri T: Being 40 or younger is an independent risk factor for relapse in operable breast cancer patients: The Saudi Arabia experience. BMC Cancer 7: 222, 2007.

3. Fredholm H, Eaker S, Frisell J, Holmberg L, Fredriksson I and Lindman $\mathrm{H}$ : Breast cancer in young women: Poor survival despite intensive treatment. PLoS One 4: e7695, 2009.

4. Anders CK, Johnson R, Litton J, Phillips M and Bleyer A: Breast cancer before age 40 years. Semin Oncol 36: 237-249, 2009.

5. Musolino A, Bella MA, Bortesi B, Michiara M, Naldi N, Zanelli P, Capelletti M, Pezzuolo D, Camisa R, Savi M, et al: BRCA mutations, molecular markers, and clinical variables in early-onset breast cancer: A population-based study. Breast 16: 280-292, 2007.

6. Klauber-DeMore N: Tumor biology of breast cancer in young women. Breast Dis 23: 9-15, 2005.

7. Smigal C, Jemal A, Ward E, Cokkinides V, Smith R, Howe HL and Thun M: Trends in breast cancer by race and ethnicity: Update 2006. CA Cancer J Clin 56: 168-183, 2006.

8. Samphao S, Wheeler AJ, Rafferty E, Michaelson JS, Specht MC, Gadd MA, Hughes KS and Smith BL: Diagnosis of breast cancer in women age 40 and younger: Delays in diagnosis result from underuse of genetic testing and breast imaging. Am J Surg 198: 538-543, 2009.

9. Mauad EC, Nicolau SM, Moreira LF, Haikel RL Jr, Longatto-Filho A and Baracat EC: Adherence to cervical and breast cancer programs is crucial to improving screening performance. Rural Remote Health 9: 1241, 2009.

10. Milani V, Goldman SM, Finguerman F, Pinotti M, Ribeiro CS, Abdalla N and Szejnfeld J: Presumed prevalence analysis on suspected and highly suspected breast cancer lesions in São Paulo using BIRADS criteria. Sao Paulo Med J 125: 210-214, 2007. 
11. Tarone RE: Breast cancer trends among young women in the United States. Epidemiology 17: 588-590, 2006.

12. Freitas-Junior R, Freitas NM, Curado MP, Martins E, Moreira MA and e Silva CM: Variations in breast cancer incidence per decade of life (Goiânia, GO, Brazil): 16-year analysis. Cancer Causes Control 19: 681-687, 2008.

13. Dutra MC, Rezende MA, de Andrade VP, Soares FA, Ribeiro MV de Paula EC and Gobbi H: Immunophenotype and evolution of breast carcinomas: A comparison between very young and postmenopausal women. Rev Bras Ginecol Obstet 31: 54-60, 2009 (In Portuguese)

14. Gnerlich JL, Deshpande AD, Jeffe DB, Sweet A, White N and Margenthaler JA: Elevated breast cancer mortality in women younger than age 40 years compared with older women is attributed to poorer survival in early-stage disease. J Am Coll Surg 208: 341-347, 2009.

15. Yancik R, Havlik RJ, Wesley MN, Ries L, Long S, Rossi WK and Edwards BK: Cancer and comorbidity in older patients: A descriptive profile. Ann Epidemiol 6: 399-412, 1996.

16. Allred DC, Harvey JM, Berardo M and Clark GM: Prognostic and predictive factors in breast cancer by immunohistochemical analysis. Mod Pathol 11: 155-168, 1998.

17. Greene FL, Page DL, Fleming ID, Fritz AG, Balch CM, Haller DG and Morrow M (eds): AJCC Cancer Staging Manual. 6th edition. Springer-Verlag, New York, pp227-229, 2002

18. Rapiti E, Fioretta G, Verkooijen HM, Vlastos G, Schäfer P, Sappino AP, Kurtz J, Neyroud-Caspar I and Bouchardy C: Survival of young and older breast cancer patients in Geneva from 1990 to 2001. Eur J Cancer 41: 1446-1452, 2005.

19. Varga D, Koenig J, Kuhr K, Strunz K, Geyer V, Kurzeder C, Atassi Z, Blettner M, Kreienberg R and Woeckel A: Comparison of early onset breast cancer patients to older premenopausal breast cancer patients. Arch Gynecol Obstet 282: 427-432, 2010.

20. Clagnan WS, Andrade JM, Carrara HH, Tiezzi DG, Reis FJ, Marana HR and Abrão RA: Age as an independent prognostic factor in breast cancer. Rev Bras Ginecol Obstet 30: 67-74, 2008 (In Portuguese)

21. Maggard MA, O'Connell JB, Lane KE, Liu JH, Etzioni DA and Ko CY: Do young breast cancer patients have worse outcomes? J Surg Res 113: 109-113, 2003.

22. Coleman MP, Quaresma M, Berrino F, Lutz JM, De Angelis R, Capocaccia R, Baili P, Rachet B, Gatta G, Hakulinen T, et al: Cancer survival in five continents: A worldwide population-based study (CONCORD). Lancet Oncol 9: 730-756, 2008.

23. Perry N, Broeders M, de Wolf C, Törnberg S, Holland R and von Karsa L: European guidelines for quality assurance in breast cancer screening and diagnosis. Fourth edition-summary document. Ann Oncol 19: 614-622, 2008

24. Chan A, Pintilie M, Vallis K, Girourd C and Goss P: Breast cancer in women <or=35 years: Review of 1002 cases from a single institution. Ann Oncol 11: 1255-1262, 2000.

25. Fowble BL, Schultz DJ, Overmoyer B, Solin LJ, Fox K, Jardines L, Orel S and Glick JH: The influence of young age on outcome in early stage breast cancer. Int J Radiat Oncol Biol Phys 30: 23-33, 1994.

26. Yildirim E, Dalgic T and Berberoğlu U: Prognostic significance of young age in breast cancer. J Surg Oncol 74: 267-272, 2000.

27. Goldstein NS, Vicini FA, Kestin LL and Thomas M: Differences in the pathologic features of ductal carcinoma in situ of the breast based on patient age. Cancer 88: 2553-2560, 2000

28. Zabicki K, Colbert JA, Dominguez FJ, Gadd MA, Hughes KS Jones JL, Specht MC, Michaelson JS and Smith BL: Breast cancer diagnosis in women $<$ or $=40$ versus 50 to 60 years: Increasing size and stage disparity compared with older women over time. Ann Surg Oncol 13: 1072-1077, 2006.
29. Berry DA, Cronin KA, Plevritis SK, Fryback DG, Clarke L, Zelen M, Mandelblatt JS, Yakovlev AY, Habbema JD and Feuer EJ; Cancer Intervention and Surveillance Modeling Network (CISNET) Collaborators: Effect of screening and adjuvant therapy on mortality from breast cancer. N Engl J Med 353: 1784-1792, 2005.

30. Tabar L, Yen MF, Vitak B, Chen HH, Smith RA and Duffy SW: Mammography service screening and mortality in breast cancer patients: 20-year follow-up before and after introduction of screening. Lancet 361: 1405-1410, 2003.

31. Gomes MC, Costa MM, Borojevic R, Monteiro AN, Vieira R, Koifman S, Koifman RJ, Li S, Royer R, Zhang S and Narod SA: Prevalence of BRCA1 and BRCA2 mutations in breast cancer patients from Brazil. Breast Cancer Res Treat 103: 349-353, 2007.

32. Risendal B, Hines LM, Sweeney C, Slattery ML, Giuliano AR, Baumgartner KB, Curtin K and Byers TE: Family history and age at onset of breast cancer in Hispanic and non-Hispanic white women. Cancer Causes Control 19: 1349-1355, 2008.

33. Bharat A, Aft RL, Gao F and Margenthaler JA: Patient and tumor characteristics associated with increased mortality in young women (<or=40 years) with breast cancer. J Surg Oncol 100: 248-251, 2009.

34. Siegelmann-Danieli N, Khandelwal V, Wood GC, Mainali R, Prichard J, Murphy TJ, Evans JF, Yumen O and Bernath AM: Breast cancer in elderly women: Outcome as affected by age, tumor features, comorbidities, and treatment approach. Clin Breast Cancer 7: 59-66, 2006.

35. Colleoni M, Rotmensz N, Robertson C, Orlando L, Viale G, Renne G, Luini A, Veronesi P, Intra M, Orecchia R, et al: Very young women $(<35$ years) with operable breast cancer: Features of disease at presentation. Ann Oncol 13: 273-279, 2002.

36. El Saghir NS, Seoud M, Khalil MK, Charafeddine M, Salem ZK, Geara FB and Shamseddine AI: Effects of young age at presentation on survival in breast cancer. BMC Cancer 6: 194, 2006.

37. Parise CA, Bauer KR, Brown MM and Caggiano V: Breast cancer subtypes as defined by the estrogen receptor (ER), progesterone receptor (PR), and the human epidermal growth factor receptor 2 (HER2) among women with invasive breast cancer in California, 1999-2004. Breast J 15: 593-602, 2009.

38. Han W, Kim SW, Park IA, Kang D, Youn YK, Oh SK, Choe KJ and Noh DY: Young age: An independent risk factor for disease-free survival in women with operable breast cancer. BMC Cancer 4: 82 , 2004.

39. Jmor S, Al-Sayer H,Heys SD, Payne S, MillerI, Ah-See A, Hutcheon A and Eremin O: Breast cancer in women aged 35 and under: Prognosis and survival. J R Coll Surg Edinb 47: 693-699, 2002.

40. Aebi S, Gelber S, Castiglione-Gertsch M, Gelber RD, Collins J, Thürlimann B, Rudenstam CM, Lindtner J, Crivellari D, Cortes-Funes $\mathrm{H}$, et al: Is chemotherapy alone adequate for young women with oestrogen-receptor-positive breast cancer? Lancet 355: 1869-1874, 2000.

41. Fernandopulle SM, Cher-Siangang P and Tan PH: Breast carcinoma in women 35 years and younger: A pathological study. Pathology 38: 219-222, 2006.

42. Gajdos C, Tartter PI, Bleiweiss IJ, Bodian C and Brower ST: Stage 0 to stage III breast cancer in young women. J Am Coll Surg 190: 523-529, 2000.

43. Sidoni A, Cavaliere A, Bellezza G, Scheibel M and Bucciarelli E: Breast cancer in young women: Clinicopathological features and biological specificity. Breast 12: 247-250, 2003. 